\title{
Variables related to periodontal disease and peri-implant bone loss
}

\section{Variáveis relacionadas à doença periodontal \\ prévia e perda óssea peri-implantar}

\author{
Ricardo Alexandre GANDRA ${ }^{1}$ iD 0000-0002-8110-7269 \\ Daniel Guião FERNANDES ${ }^{1}$ iD 0000-0002-5492-4263 \\ Iolanda L. Gomes Bianco da SILVA ${ }^{1}$ iD 0000-0002-4596-0844 \\ Elton Gonçalves ZENÓBIO' ${ }^{1}$ iD 0000-0002-0537-1535
}

\section{ABSTRACT}

The replacement of missing teeth by implant retained prostheses is a predictable form of rehabilitation in the population as a whole. Due to the similarity between periodontal disease and peri-implantitis, the hypothesis is inferred that patients with a history of periodontal disease would be more susceptible to peri-implantitis. This concept has been discussed and supported by new scientific evidence. The purpose of this review was to evaluate whether there is any relationship between periodontitis and greater peri-implant bone loss in periodontally compromised patients. The pertinent literature has concluded that rehabilitation by means of implants in patients with a history of periodontal disease was predictable and has shown success rates similar to those obtained in patients with no history of periodontitis.

Indexing terms: Alveolar bone loss. Dental implants. Periodontitis. Peri-implantitis.

\section{RESUMO}

A substituição dos dentes ausentes, por próteses implanto retidas, é uma forma previsível de reabilitação na população como um todo. Devido à similaridade da doença periodontal com a periimplantite, infere-se a hipótese de que pacientes com histórico de doença periodontal seriam mais suceptíveis a periimplantite. Este conceito vem sendo discutido e suportado por novas evidencias científicas. O objetivo desta revisão é avaliar se pacientes historicamente periodontalmente comprometidos apresentam relação com maior perda óssea peri-implantar. A literatura pertinente conclui que a reabilitação por meio de implantes em pacientes com histórico de doença periodontal é previsivel e com índice de sucesso semelhantes pacientes sem histórico de periodontite.

Termos de indexação: Perda do osso alveolar. Implantes dentários. Periodontite. Peri-implantite.

\section{INTRODUCTION}

The process of peri-implantitis consists of periimplant bone loss after inflammation of the peri-implant tissues, essentially associated with bacterial infection. In addition, factors such as systemic diseases, smoking, poor oral hygiene, occlusal overload, characteristics of the prosthetic crown, position, shape, surface and type of

\footnotetext{
$\boldsymbol{\nabla} \boldsymbol{\nabla} \boldsymbol{\nabla}$
}

1 Pontifícia Universidade Católica de Minas Gerais, Departamento de Odontologia. Av. Dom José Gaspar, 500, Prédio 46, Sala 214, 30535 901, Coração Eucarístico, Belo Horizonte, MG, Brasil.

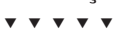


implant system may be involved with peri-implant bone loss.

In this context, peri-implant bone loss is characterized as a consequence of the association of innumerable characteristic conditions. Therefore, clinical periodontal parameters such as bleeding on probing, suppuration, isolated regions of bone loss are not sufficient to characterize peri-implantitis $[1,2]$.

Due to the similarity between periodontal disease and peri-implantitis, the hypothesis arose that patients with a history of periodontal disease might be more susceptible to peri-implantitis, considering that the presence of bone loss around the implant is greater in periodontally compromised patients. The microbiota associated with peri-implantitis is similar to that found in chronic periodontitis, including the following pathogens: Actinobacillus actinomycetemcomitans, Porphyromonas gingivalis, Prevotella intermedia, Tanarella forsythensis and Treponema denticola [3,4]. However, when the histopathological characteristics of periodontitis and peri-implantitis are compared, different histopathological characteristics have been reported in the two types of lesions [5].

The susceptibility of individuals to the periodontal disease process is probably a determinant factor. Approached in in a systematic review [6], studies have emphasized a greater degree of peri-implant bone loss in periodontally compromised patients in comparison with those who were periodontally healthy and suggested increased susceptibility of these patients, seeing that the majority of individuals diagnosed with advanced or aggressive periodontitis continued to have this condition when they were submitted to implant placement therapy. However, this hypothesis did not necessarily apply to the milder forms of periodontitis. Nevertheless, the lack of control of the factors common to periodontitis and peri-implantitis and the diversity of studies with varied methodologies limited the ability to extract conclusive information [7].

Dental implants are seen as a good option for replacing missing teeth, because they present high success and survival rates. Reports on the prevalence of peri-implantitis are very variable, but the presence of periodontal disease has been perceived to be a possible risk factor. Treatment with implants inpatients with periodontal disease must not be performed without a complete evaluation and stabilization of this problem [8].
In view of the pertinent literature available up to now, this study considered the evidence that there could be an association between periodontitis and peri-implantitis bone loss in periodontally compromised patients.

\section{REVIEW}

Articles were grouped by specificity of the question relative to the review proposed in the last 15 years. The main systematic reviews that also contemplated the question were grouped.

As in the case of periodontal diseases, patients submitted to implant placement therapy could develop inflammatory processes and culminate in the loss of the implant. However, the pathogenic mechanism of the development of peri-implant diseases is not well defined, since innumerable factors may be present in the progression of peri-implant bone loss [9].

Periodontally compromised patients with partial tooth losses and history of periodontal disease, taking into account the following factors: plaque index, tobacco use, type of periodontitis, position and type of implant, and those undergoing supporting periodontal therapy were evaluated. It was concluded that the prevalence of inflammatory peri-implant disease was significantly related to the increase in plaque index, type of periodontitis and localization of the implant [10].

Periodontists play an extremely important role in complex cases, to achieve the needs of reconstruction, insertion and maintenance of implants, leading to a healthy condition in the long term [11].

Peri-implantitis is disease that has major impact on implant failures; it is known to have a microbiota similar to that associated with periodontitis [12]. One research compared the clinical, radiographic and microbiological aspects between the tooth and implant to evaluate the success rate of implants in a period of 3 years in patients with chronic, aggressive periodontitis and in periodontally healthy patients, the results indicated that bone loss and loss of attachment were slightly higher in the group of patients with aggressive periodontitis, both in the teeth and implants [13].

The premise that the periodontal condition interfered in the peri-implant status encouraged researchers to compare the clinical and radiographic changes in the tissues adjacent to the teeth and implant and evaluate the 
potential risk factors that could aggravate the periodontal conditions, whose characteristics could influence the state of the peri-implant tissues. Evidence showed that periodontal parameters such as a high plaque index, greater probing depth, low attachment level, and bleeding on probing demonstrated that unfavorable periodontal conditions could influence the tissues and bone loss in periimplant tissues. This loss could be aggravated by factors such as tobacco use, health problems and position of the implant in relation to the circumjacent tissues.

In this context, patients with a previous history of chronic periodontitis, who had teeth replaced with implants presented greater clinical and biological problems when compared with those who received implants for other reasons $[14,15]$. As far as the severity of chronic periodontitis was concerned, researchers [16] evaluated the health of the peri-implant tissues in patients with various stages of the disease, and confirmed a higher level of bone loss in implants inserted in these patients with severe periodontitis as opposed to those with the milder forms of the disease.

However, it must be considered that the diverse methodologies could have generated variability in the results. Therefore, a study that covered a large sample and investigated whether patients with a history of moderate to severe periodontitis were at greater risk for complications with the implant when compared with periodontally healthy patients. The study concluded that there was no significant impact on implant failure in a period of 5 years after insertion of the prostheses [17].

A systematic review with meta-analysis that evaluated the risk factors for peri-implantitis indicated that a history of periodontitis could be associated with a possible risk for peri-implantitis. However, there was insufficient evidence in the literature for analyzing the role of smoking in this context [18].

A retrospective analysis was conducted to evaluate the risk factors that could aggravate lesions in the periimplant tissues and implant survival. Factors such as gender, systemic conditions, smoking, history of periodontitis, length, diameter and position of the implant were evaluated. Thus it was demonstrated that permanence in the long term was compatible with well positioned implants, however, the presence of factors such as tobacco use, periodontal disease, implants in the posterior region of the maxilla increased the number implant failures [19].
Individuals who needed extractions in periodontally compromised regions, and insertion of implants in fresh alveoli were selected for a prospective study. Implants were inserted and prostheses placed after 3 months. Radiographic exams performed during the 3 years of follow-up showed high survival rates to the value of $98.66 \%$ [20]. In fact, when immediate implants were evaluated in patients with periodontal disease in a 5-year prospective study survival rates of $97.9 \%$ and $99.4 \%$ were obtained in 5 years of follow-up [21].

Whereas, one study concluded that peri-implantitis in Korean patients with a history of periodontal disease was similar to that in patients of other populations, and that single implants appeared to be less susceptible to periimplantitis when compared with implants that supported multiples prostheses [22].

Peri-implantitis is not an uncommon complication of implant placement therapy. A higher prevalence of periimplantitis was identified for patients with presence or history of periodontal disease and for smokers. Up to now, no true risk factor for peri-implantitis has been established. Maintenance and support programs are essential for the long term success of treatment with implants [21].

Data from pre-existent studies have pointed out a fundamental risk of smoking and diabetes as systemic factors associated with peri-implantitis. However, evidence is still immature. The specific contribution of general health problems to the development of peri-implantitis requires more robust clinical and epidemiological investigations.

A consensus about etiological factors and risk factors for peri-implantitis provided a strong body of evidence that the microbiological flora could help with the development of peri-implantitis. It could be concluded that the material of the implant, its shape, surface characteristics, procedures and biomaterials used for bone augmentation, undue prosthetic procedures and inadequate biomechanical planning may also be risk factors for the occurrence and progression of peri-implantitis [23].

In spite of the limitation of evidence available, two studies concluded that implants inserted in patients previously treated for periodontal disease were associated with a higher incidence of biological complications and lower success and survival rates than implants inserted in periodontally healthy patients $[24,25]$.

Based on the results of a systematic review to evaluate the influence of the smoking habit and history 
of periodontal disease as risk factors for implant loss and occurrence of peri-implantitis, we could conclude that there is limited evidence for suggesting that the history of periodontal disease could be a risk for peri-implantitis. There are insufficient data for evaluating the role of smoking in implant loss and peri-implantitis. Long term prospective studies of impact are necessary for analyzing the role of these potential risk factors, with the use of clear and accepted definitions of disease, accurate selection of samples and strict control of confounding factors [26].

There is strong evidence in the literature that the new generation of dental implants, with moderately rough surface topography produce better results in terms of implant survival, when compared with the previous generations. Especially when considering that the surgical and prosthetic protocols used at present are more challenging. Furthermore, patients with compromised systemic conditions, who have been shown more propensity to implant failures and other complications in the last four decades, may be treated in a more predictable manner today. However, in spite of the influence of surface topography on the implant survival rate being well known, there is a lack of systematic evaluation in the literature, focusing on the effect of this topography on peri-implant bone loss.

\section{DISCUSSION}

Patients who are submitted to the replacement of teeth by dental implants are subject to the possibility of undergoing inflammatory and/or infectious processes in the peri-implant tissues, and these may be of varied intensities. This determines both the quantity of bone loss and the success of the implant. The prognosis of each case may be related to the previous experience of periodontal disease of each individual, making a definitive interpretation about the aspect inconclusive as yet, due to various confounding factors that may influence the manifestation of disease.

The literature has demonstrated that severe chronic periodontitis as well as the aggressive type exhibited a greater chance of being related to implant failure $[3,6,7,9,10,13-15]$. However, these results must be analyzed with caution, because studies that have evaluated this context varied in their methodologies and results.

Important to emphasize is that deficient oral hygiene and smoking have a negative influence on the predictability of treatment with implants $[1,6,19,23$ $25,27]$.

Although the literature affirms that the immediate insertion of implants in alveoli with periodontal lesions may lead to loss of the implant [20], this procedure has been shown to be feasible provided that the implant is not placed in the presence of an acute inflammatory process [21].

In view of the contemporary state of the literature, patients with a history of periodontitis who are submitted to therapy with implants must be warned about the higher risk of compromise of peri-implant tissues, in spite of the limitations inherent to studies in this context [25].

\section{CONCLUSION}

According to the review conducted, it was concluded that rehabilitation by means of implants in patients with a history of periodontal disease is predictable and has a success rate similar to that of patients without a history of periodontitis. However, some individuals may experience inflammatory processes during implant survival with an outcome that is as yet not predictable. Longitudinal studies and well-designed methodologies must be conducted with the purpose of elucidating the association, and providing a better understanding of the pathogenesis of peri-implantitis.

\section{Collaborators}

RA GANDRA, identify databases, define keywords, search and select articles. Writing of literary research. DG GONÇALVEZ, identify databases, define keywords, search and select articles. Writing of literary research. IL BIANCO, search and selection of articles. Writing of literary research. EG ZENÓBIO, advisor, definition of the central question and structuring of the literary research. Search Review.

\section{REFERENCES}

1. Vázquez ÁR, Pérez SM, Gayoso DP, Garcia GA. Factors affecting Peri-implant bone loss: a post-five years retrospective study. Clin Oral Impl Res. 2015; 26(9):1006-1014. http://dx.doi. org/10.1111/cl.12416

2. Mombelli A, Müller N, Cionca N. The epidemiology of periimplantitis. Clin Oral Implants Res. 2012;23(6):67-76. http:// dx.doi.org/10.1111/j.1600-0501.2012.02541.x 
3. Matarasso S, Rasperini G, lorio Siciliano V, Salvi GE, Lang NP, Aglietta M. A 10-year retrospective analysis of radiographic bone-level changes of implants supporting single-unit crows in periodontally compromised vc. Periodontally healthy patients. Clin Oral Impl Res. 2010; 21(1):898-903. https://doi. org/10.1111/j.1600-0501.2010.01945.x

4. Charalampakis G, Rabe P, Leonhardt A, Dahlén G. A followup study of peri-implantitis cases after treatment. J Clin Periodontol. 2011;38(9):864-871.

5. Berglundh T, Zitzmann NU, Donati M. Are peri-implantitis lesions different from periodontitis lesions? J Clin Periodontol. 2011;38(11):188-202.

6. Safii SH, Palmer RM, Wilson RF. Risco de falha do implante e perda óssea marginal em indivíduos com história de periodontite: uma revisão sistemática e meta-análise. Clin Implant Dent Relat Res. 2010;12(3):165-74. http://dx.doi. org/10.1111/j.1708-8208.2009.00162.x

7. Glietta M, Siciliano VI, Rasperini G, Cafiero C, NP Lang, Salvi GE. 10 anos análise retrospectiva de alterações do nível ósseo marginal ao redor de implantes em periodontalmente saudáveis e periodontalmente comprometidos fumantes. Clin Oral Implantes Res. 2011;22(1):47-53. http://dx.doi. org/10.1111/ j.1600-0501.2010.01977.x

8. King E, Patel R, Patel A, Addy L. Should implants be considered for patients with periodontal disease?. 2016;221(11):705-711. http://dx.doi.org/10.1038 / sj.bdj.2016.905

9. Cho-Yan Lee J, Mattheos N, Nixon KC, Ivanovski. Residual periodontal pockets are a risk indicator for peri-implantitis in patients treated for periodontitis. Clin Oral Impl Res. 2012;23(3):325-333. http://dx.doi.org/10.1111 / j.1600-0501. 2011.02264.x

10. Aguirre-Zorzano LA, Estefanía-Fresco R, Telletxea O, Bravo M. Prevalence of Peri-implant inflammatory disease in patients with a history of periodontal disease who receive supportive periodontal therapy. Clin Oral Impl Res. 2015;26(11):1338-1344.

11. Matarese G, Ramaglia L, Fiorillo L, Cervino G, Lauritano F, Isola G. Implantology and Periodontal Disease: The Panacea to Problem Solving? Open Dent J. 2017;30(11):460-465. http://dx.doi.org/10.2174/1874210601711010460

12. Mombelli A. Etiology, diagnosis and treatment considerations in peri-implantitis. Curr Opin Periodontol. 1997; 4(1):127-136.

13. Mengel R, Flores-de-Jacoby L. Implants in patients treated for generalized aggressive and chronic periodontitis: A 3-year prospective longitudinal study. 2005;76(4):534-5443.

14. Karoussis IK, Müller S, Salvi GE, Heitz-Mayfield LJA, Brägger $U$, Lang NP. Association between periodontal and peri-implant conditions: A 10-year prospective study. Clin Oral Impl Res. 2004;15(1):1-7. https://doi.org/10.1111/j.1600-0501.2004. 00982.x

15. Karoussis IK, Salvi GE, Heitz-Mayfield LJA, Brägger U, Hämmerle CHF, Lang NP. Long-term implant prognosis in patients with and without a history of chronic periodontitis; a 10-year prospective cohort study of the ITI Dental implant system. Clin Oral Impl Res. 2003;14(3):329-339. https://doi. org/10.1034/j.1600-0501.000.00934.x

16. Aloufi F, Bissada N, Ficara A, Faddoul F, Al-Zahrani MS. Clinical assessment of peri-implant tissues in patients with varying severity of chronic periodontitis. Clin Implant Dent Relat Res. 2009;11(1):37-40. http://dx.doi.org/10.1111 / j.1708-8208. 2008.00087.x

17. Gianserra R, Cavalcanti R, Oreglia F, Manfredonia MF, Esposito M. Outcome of dental implants in patients with and without a history of periodontitis: a 5-year pragmatic multicentre retrospective cohort study of 1727 patients. Eur J Oral Implantol. 2010;3(4):307-14.

18. Stacchi C, Berton F, Perinetti G, Frassetto A, Lombardi T, Khoury $A$, et al. Risk Factors for Peri-Implantitis: Effect of History of Periodontal Disease and Smoking Habits. A Systematic Reviewand Meta-Analysis. J Periodontal Implant Sci. 2017;47(4):240-250. http://dx.doi.org/10.5037/jomr. 2016.7303

19. Morales-Vadillo R, Leite FP, Guevara-Canales J, Netto HD, Cruz F, Cruz G, et al. Retrospective study of the survival and associated risk factors of wedge-shaped implants. Int J Oral Maxillofac Implants. 2013;28(3):875-82. http://dx.doi. org/10.11607 / jomi.2821

20. Crespi R, Capparé P, Crespi G, Giudice G, Gastaldi G, Gherlone E. Dental implants placed in periodontally infected sites in humans. Clin Implant Dent Relat Res. 2017;19(1):131-139. http://dx.doi.org/10.1111/ cid.12425

21. Maló P, Nobre MA, Lopes A, Ferro A, Gravito I. Immediate loading IF implants placed in patients with untreated periodontal disease: A 5-year prospective cohort study. Eur J Oral Implantol. 2014;7(3):295-304.

22. Goh MS, Hong EJ, Chang M. Prevalence and risk indicators of peri-implantitis in Korean patients with a history of periodontal disease: a cross-sectional study. J Periodontal Implant Sci. 2017;47(4):240-250. http://dx.doi.org/10.5051 / jpis. 2017.47.4.240

23. Marcantonio C, Nicoli LG, Marcantonio Junior E, ZandimBarcelos DL. Prevalence and Possible Risk Factors of Periimplantitis: A Concept Review. J Contemp Dent Pract. 2015;16(9):750-7.

24. Turri A, Rossetti PH, Canullo L, Grusovin MG, Dahlin C. Prevalence of periimplantitis in medically compromised patients and smokers: a systematic review. Int J Oral Maxillofac Implants. 2016;31(1):111-8. http://dx.doi.org/10.11607 / jomi. 4149

25. Canullo L, Schlee M, Wagner W, Covani U. International brainstorming meeting on etiologic and risk factors of periimplantitis, Montegrotto (Padua, Italy), August 2014. Int J Oral Maxillofac Implants. 2015;30(5):1093-104. http://dx.doi. org/10.11607 / jomi.4386

26. Veitz-Keenan A, Keenan JR. Implant outcomes poorer in patients with history of periodontal disease. Evid Based Dent. 2017;18(1):5. http://dx.doi.org/10.1038/sj.ebd.6401214

27. Sousa V, Mardas N, Farias B, Petrie A, Needleman I, Spratt $D$, et al. A systematic review of implant outcomes in treated periodontitis patients. Clin Oral Implants Res. 2016;27(7):787-844. http://dx.doi.org/10.1111/ cl.12684

Received on: 1/4/2018 Final version resubmitted on: 30/10/2018 Approved on: 5/12/2018 